\title{
Sphingobacterium detergens sp. nov., a surfactant- producing bacterium isolated from soil
}

Correspondence

Ana M. Marqués

ammarques@ub.edu
During screening experiments for new biosurfactants, several soil samples from the Azores Islands were analysed. Strain $6.2 S^{\mathrm{T}}$ was selected for its ability to reduce the surface tension of the medium to $32 \mathrm{mN} \mathrm{m}^{-1}$ due to the production of a mixture of compounds with surface activity (Burgos-Díaz et al., 2011). This strain was initially identified as Sphingobacterium multivorum, based on cell and colony morphology, as well as the results of the API 20 NE bacterial identification kit. The results of 16S rRNA gene sequence analysis showed that strain $6.2 \mathrm{~S}^{\mathrm{T}}$ belonged to the genus Sphingobacterium, and that its nearest relative was Sphingobacterium siyangense. The aim of the present study was to clarify the taxonomic position of this new strain by using a polyphasic approach, including pheno-

†These authors contributed equally to this work.

The GenBank/EMBL/DDBJ accession numbers for the 16S rRNA and cpn60 gene sequences of strain $6.2 S^{\top}$ are JN015213 and JN015214, respectively.

Two supplementary figures are available with the online version of this paper. typic, chemotaxonomic, genotypic and phylogenetic analyses.

The family Sphingobacteriaceae belongs to the phylum Bacteroidetes and is composed of eight genera (Sphingobacterium, Pedobacter, Mucilaginibacter, Nubsella, Olivibacter, Parapedobacter, Pseudosphingobacterium and Solitalea) of bacteria commonly isolated from the environment (http:// www.bacterio.cict.fr). The genus Sphingobacterium was established by Yabuuchi et al. (1983), based on the presence of high concentrations of sphingophospholipids in cellular lipid components. Two species of the genus Flavobacterium were reclassified as members of this new genus (Sphingobacterium multivorum and Sphingobacterium spiritivorum) and an additional species (Sphingobacterium mizutae) was recognized. Members of the genus Sphingobacterium are Gram-negative-staining rods, that give a positive reaction for catalase and oxidase, a negative reaction for heparinase, gelatinase and indole production and have iso- $\mathrm{C}_{15: 0}$, iso$\mathrm{C}_{15: 0} 2-\mathrm{OH}, \mathrm{C}_{16: 1} \omega 7 c$ and $\mathrm{C}_{17: 0} 3-\mathrm{OH}$ as the main fatty acids (Kim et al., 2006; Liu et al., 2008). These organisms are frequently isolated from soil, compost or activated sludge and occasionally from clinical specimens (Yabuuchi et al., 1983; 
Freney et al., 1987). At the time of writing, the genus Sphingobacterium comprises 17 recognized species: Sphingobacterium alimentarium (Schmidt et al., 2012), S. anhuiense (Wei et al., 2008), S. antarcticum (Shivaji et al., 1992), S. bambusae (Duan et al., 2009), S. canadense (Mehnaz et al., 2007), S. composti (Ten et al., 2006), S. daejeonense (Kim et al., 2006), S. faecium (Takeuchi \& Yokota, 1992), S. kitahiroshimense (Matsuyama et al., 2008), S. lactis (Schmidt et al., 2012), S. mizutaii (Yabuuchi et al., 1983), S. multivorum (Yabuuchi et al., 1983), S. shayense (He et al., 2010), S. siyangense (Liu et al., 2008), S. thalpophilum (Takeuchi \& Yokota, 1992), S. wenxiniae (Zhang et al., 2012) and the type species of the genus S. spiritivorum (Yabuuchi et al., 1983). Eleven of these species have been described in the last seven years. Two other previously described members of the genus Sphingobacterium have been reclassified as members of the genus Pedobacter as Pedobacter heparinus and Pedobacter piscium (Steyn et al., 1998).

Strain $6.2 \mathrm{~S}^{\mathrm{T}}$, a Gram-negative-staining, aerobic, nonspore-forming bacillus, was isolated from a soil sample after cultivation in a mineral salt medium with a carbon source pool $\left(0.5 \%\right.$ sodium citrate, $0.5 \% \mathrm{C}_{11-13}$ and $0.5 \%$ yeast extract) for 7 days at $30{ }^{\circ} \mathrm{C}$ and 150 r.p.m. After two subcultures, a dilution $\left(10^{-5}\right)$ was spread onto TSA. Isolated colonies were studied for surfactant production (Burgos-Díaz et al., 2011) and routinely cultured on TSA plates. Stock cultures were maintained in Cryo-Beads (AES CHEMUNEX) at $-80{ }^{\circ} \mathrm{C}$.

Genomic DNA was extracted using the REALPURE genomic DNA extraction kit (Durviz). PCR amplification and sequencing of $16 \mathrm{~S}$ rRNA and chaperonin 60 (cpn60) genes were performed using universal primers and previously described methods (Martínez-Murcia et al., 1999; Mehnaz et al., 2007). For cpn60 gene amplification, a second pair of primers was designed using the Primer3 program (Rozen \& Skaletsky, 2000) to improve PCR specificity for strain $6.2 \mathrm{~S}^{\mathrm{T}}$. The forward and reverse primers designed were cpn60-F (5'-GCAATCGTTGCTCCAGGTAT- $3^{\prime}$ ) and cpn60-R (5'-GTTGCNANTGCCTCACCATC- $3^{\prime}$ ) to amplify a $\sim 500$ bp region of the cpn60 gene. The nucleotide sequences obtained were compared with available gene sequences retrieved from GenBank/ EMBL/DDBJ databases using the BLAST program (http:// blast.ncbi.nlm.nih.gov/Blast.cgi). Multiple sequence alignments were performed using CLUSTAL_X software version 2.0 (Larkin et al., 2007). Phylogenetic trees were constructed from a distance matrix corrected with Kimura's two-parameter model (Kimura, 1980) using the neighbour-joining method (Saitou \& Nei, 1987) and MEGA4 software (Tamura et al., 2007). The robustness of the tree topology was evaluated by bootstrap analysis based on 1000 replications.

An almost complete 16S rRNA gene sequence (1483 bp) of strain $6.2 \mathrm{~S}^{\mathrm{T}}$ was obtained (GenBank accession no. JN015213). Phylogenetic analysis based on the 16S rRNA gene sequence revealed that strain $6.2 S^{\mathrm{T}}$ is a member of the genus Sphingobacterium, which formed a robust cluster with four type strains of this genus (Fig. 1). Strain $6.2 \mathrm{~S}^{\mathrm{T}}$ was most closely related to S. siyangense $\mathrm{SY}^{\mathrm{T}}(98.9 \%$ similarity), S. canadense CR $11^{\mathrm{T}}$ (98.8\%), S. multivorum JCM $21156^{\mathrm{T}}(98.6 \%)$ and S. thalpophilum DSM $11723^{\mathrm{T}}$ $(96.8 \%)$. Partial chaperonin 60 (cpn60) gene sequence analysis was useful in resolving phylogenetic relationships between strain $6.2 S^{T}$ and the most closely related taxa of the genus Sphingobacterium (Fig. 2). The cpn60 sequences for isolate $6.2 \mathrm{~S}^{\mathrm{T}}(503 \mathrm{bp})$ and S. siyangense $\mathrm{SY}^{\mathrm{T}}(558 \mathrm{bp})$ were determined and have been deposited in the GenBank database under accession numbers JN015214 and JN015215, respectively. The sequence similarities of strain $6.2 S^{\mathrm{T}}$ ranged from $85.5 \%$ with S. thalpophilum DSM $11723^{\mathrm{T}}$ to $90.3 \%$ with S. canadense CR $11^{\mathrm{T}}$ and S. multivorum JCM $21156^{\mathrm{T}}$. When determining the evolutionary relationships of strain $6.2 S^{\mathrm{T}}$ by sequence analysis, the interrelationships inferred from the cpn60 gene-based phylogeny had better resolution than those based on 16S rRNA gene sequences.

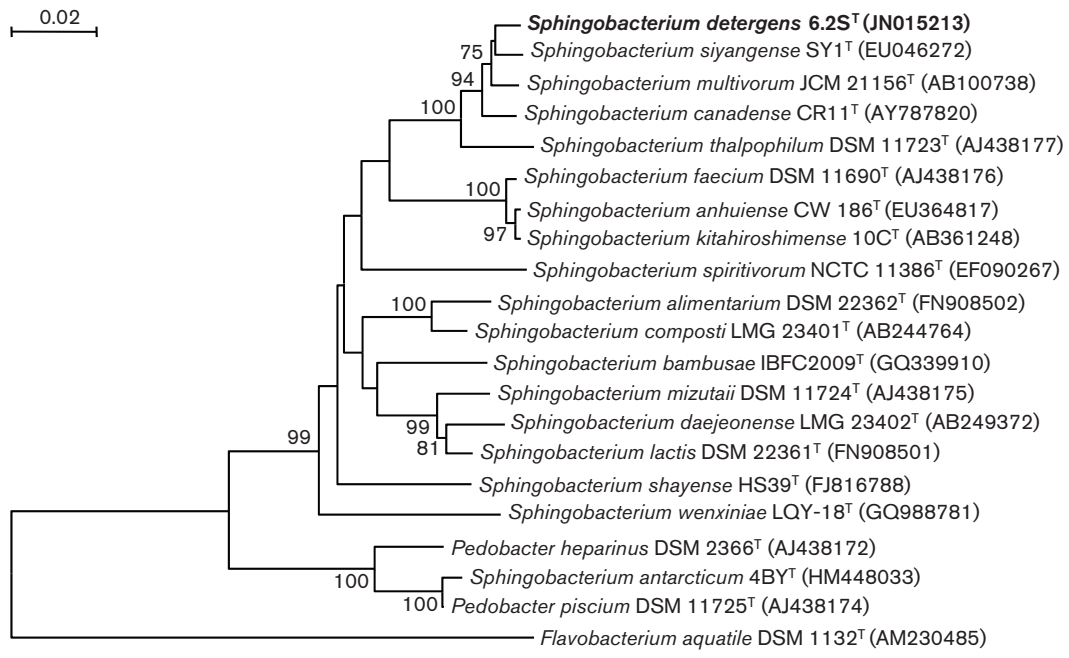

Fig. 1. Neighbour-joining phylogenetic tree based on 16S rRNA gene sequences showing the relationships between strain $6.2 S^{\top}$ and members of the genus Sphingobacterium, including two species later reclassified in the genus Pedobacter ( $P$. heparinus and $P$. piscium). Flavobacterium aquatile DSM $1132^{\top}$ was used as an outgroup. GenBank accession numbers are shown in parentheses. Bootstrap values (expressed as percentages of 1000 replications) $>70 \%$ are given at branch points. Bar, 0.02 substitutions per nucleotide position. 


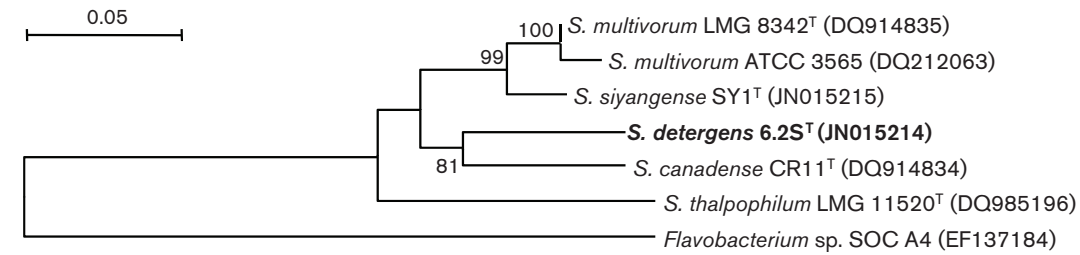

Fig. 2. Neighbour-joining phylogenetic tree based on cpn60 gene sequences showing the position of strain $6.2 S^{\top}$ and its closest relatives within the genus Sphingobacterium. Flavobacterium sp. SOC A4 was used as an outgroup. GenBank accession numbers are shown in parentheses. Bootstrap values (expressed as percentages of 1000 replications) $>70 \%$ are given at branch points. Bar, 0.05 substitutions per nucleotide position.

These results also confirmed that strain $6.2 S^{\mathrm{T}}$ was a separate species of the genus Sphingobacterium.

For DNA-DNA hybridization experiments and determination of DNA G + C content, genomic DNA was prepared according to a modification of the procedure of Wilson (1987). DNA-DNA hybridizations were performed in the presence of $50 \%$ formamide at $37{ }^{\circ} \mathrm{C}$ according to a modification of the method by Ezaki et al. (1989). The DNA base composition was determined using HPLC (Mesbah et al., 1989). The $\mathrm{G}+\mathrm{C}$ content of the chromosomal DNA was determined as the mean of three independent analyses. These analyses were performed by the BCCM/LMG Identification Service (Gent, Belgium). The results obtained are summarized in Table 1. The DNA-DNA hybridization values of strain $6.2 S^{\mathrm{T}}$ with the closely related type strains of the genus Sphingobacterium were clearly lower than $70 \%$ (19-39\% DNA-DNA relatedness), the generally accepted limit for species delineation (Wayne et al., 1987). These results confirmed that the new strain did not belong to a recognized species of the genus Sphingobacterium. The DNA G + C content of strain $6.2 S^{T}$ was $40 \mathrm{~mol} \%$. This value was within the range of DNA $\mathrm{G}+\mathrm{C}$ contents found previously for species of the genus Sphingobacterium (39-42 mol\%) as reported in the second edition of Bergey's Manual of Systematic Bacteriology (Krieg et al., 2010).

Morphological features were examined after incubation for $24 \mathrm{~h}$ at $30{ }^{\circ} \mathrm{C}$ on TSA by negative staining using transmission electron microscopy (J1010; JEOL). Gram staining and endospore-forming features were investigated using a light microscope ( $\mathrm{CH}-2$; Olympus) according to the method described by Chapin \& Lauderdale (2003). Growth at different temperatures $\left(4-42{ }^{\circ} \mathrm{C}\right)$ was investigated using TSA (Pronadisa) as the basal medium. Tolerance of $\mathrm{NaCl}$ was tested using nutrient agar (Panreac) supplemented with concentrations of $\mathrm{NaCl}$ of $0-6.5 \%$ (w/ v) after 5 days of incubation. Growth was assessed at pH 3-11. Growth on MacConkey agar (Oxoid) and cetrimide agar (Oxoid) was evaluated at $30{ }^{\circ} \mathrm{C}$ after $24 \mathrm{~h}$ incubation. Unless otherwise indicated, the phenotypic characteristics were examined using standard procedures (MacFaddin, 1980; Barrow \& Feltham, 1993; Chapin \& Lauderdale, 2003) and all experiments were conducted in triplicate. The following analytical procedures were performed. Gelatinase activity was studied according to the method of Pochon \& Tardieux (1962). Citrate utilization was determined on Simmons' citrate agar (Oxoid). Oxidase activity was tested by determining

Table 1. DNA G $+C$ content and DNA-DNA hybridization values between strain $6.2 S^{\top}$ and closely related type strains of the genus Sphingobacterium

Strains: $1,6.2 S^{\mathrm{T}} ; 2$, S. siyangense KCTC $22131^{\mathrm{T}}$; 3, S. multivorum DSM $11691^{\mathrm{T}}$; 4, S. canadense LMG $23727^{\mathrm{T}}$. Results of DNA-DNA hybridization experiments are expressed as the mean of four determinations. The values given in parentheses are the differences between the reciprocal values.

\begin{tabular}{|c|c|c|c|c|c|}
\hline \multirow[t]{2}{*}{ Strain } & \multirow{2}{*}{$\begin{array}{c}\text { DNA G }+ \text { C content } \\
(\mathrm{mol} \%)\end{array}$} & \multicolumn{4}{|c|}{ DNA-DNA relatedness (\%) } \\
\hline & & 1 & 2 & 3 & 4 \\
\hline $6.2 \mathrm{~S}^{\mathrm{T}}$ & 40.0 & 100 & & & \\
\hline S. siyangense KCTC $22131^{\mathrm{T}}$ & $40.5^{*}$ & $20(3)$ & 100 & & \\
\hline S. multivorum DSM $11691^{\mathrm{T}}$ & $38.5^{*}$ & $39(2)$ & $20(1)$ & 100 & \\
\hline S. canadense LMG $23727^{\mathrm{T}}$ & $39.9-40.5^{*}$ & $19(1)$ & $66(8)$ & $21(4)$ & 100 \\
\hline
\end{tabular}

${ }^{*}$ Data from Krieg et al. (2010). 
the oxidation of $(1 \%) \mathrm{N}, \mathrm{N}, \mathrm{N}^{\prime}, \mathrm{N}^{\prime}$-tetramethyl-3-p-phenylene-diamine solution (Merck) and catalase activity was evaluated by determining the production of oxygen bubbles in a $5 \%(\mathrm{v} / \mathrm{v})$ aqueous hydrogen peroxide solution. Single carbon-source utilization was determined as described by Kim et al. (2006). To this medium a trace element solution (Marqués et al., 2009) and a selenite/ tungstate solution (Tschech \& Pfennig, 1984) were added and the $\mathrm{pH}$ was adjusted to 6.8. This medium was aliquoted in small tubes and filter-sterilized carbon sources were added to each tube $(0.1 \% \mathrm{w} / \mathrm{v})$. Tubes were incubated at $30{ }^{\circ} \mathrm{C}$ for 7 days and growth was examined visually. Positive and negative controls were added. Other physiological characteristics were determined with an API $20 \mathrm{NE}$ gallery according to the instructions of the manufacturer (bioMérieux). Antibiotic sensitivity tests were performed using the diffusion method described by Jorgensen \& Turnidge (2003) with discs (bioMérieux) containing the following antibiotics $(\mu \mathrm{g})$ : ampicillinclavulanic acid (30), ampicillin (10), aztreonam (30), amikacin (30), cephalotin (30), cefoxitin (30), ceftriaxone (30), ciprofloxacin (5), colistin (50), chloramphenicol (30), erythromycin (15), streptomycin (10), fosfomycin (50), gentamicin (10), imipenem (10), tetracycline (30), ticarcillin (75), tobramycin (10) and trimethoprimsulfamethoxazole (1.25-23.75). After $20 \mathrm{~h}$ of incubation, the diameters of the inhibition zones were measured.

Strain $6.2 S^{\mathrm{T}}$ formed round, wet, beige colonies of $3-5 \mathrm{~mm}$ diameter when grown for $48-72 \mathrm{~h}$ on TSA at $30{ }^{\circ} \mathrm{C}$. Cells of $6.2 \mathrm{~S}^{\mathrm{T}}$ were non-motile rods that were $2.5-1.8 \mu \mathrm{m}$ long and $1.0-0.8 \mu \mathrm{m}$ wide (see Fig. S1 in IJSEM Online). The physiological and biochemical properties that differentiate strain $6.2 S^{\mathrm{T}}$ from related species of the genus Sphingobacterium are shown in Table 2 .

For fatty acid analysis, strain $6.2 \mathrm{~S}^{\mathrm{T}}$ was grown in TSA at $30{ }^{\circ} \mathrm{C}$ for $24 \mathrm{~h}$. The cellular fatty acid profile of strain $6.2 \mathrm{~S}^{\mathrm{T}}$ was determined by using a Microbial ID system equipped with a GC (5890 Series II; Hewlett Packard) and Sherlock version 4.0 of the aerobic library (Microbial ID, 1993). The cellular fatty acids mainly comprised summed feature 3 (iso- $\mathrm{C}_{15: 0} 2-\mathrm{OH}$ and/or $\left.\mathrm{C}_{16: 1} \omega 7 c\right)(43.71 \%)$, iso- $\mathrm{C}_{15: 0}$ (20.91\%), iso- $\mathrm{C}_{17: 0} 3-\mathrm{OH}(7.40 \%)$ and $\mathrm{C}_{16: 0}(7.33 \%)$. The cellular fatty acids of strain $6.2 \mathrm{~S}^{\mathrm{T}}$ are listed in Table 3 and are compared with the four type strains that formed a closely related cluster in the genus Sphingobacterium. The fatty acid profile of strain $6.2 S^{\mathrm{T}}$ resembled those of closely related strains of species of the genus Sphingobacterium. The sphingolipid assay was resolved by two-dimensional TLC as previously described (Mehnaz et al., 2007). The major lipid was phosphatidylethanolamine and several unknown lipids were also detected. Sphingolipid, which is a distinct feature of the members of the genus Sphingobacterium, was also present (Fig. S2).

On the basis of phenotypic and chemotaxonomic properties and phylogenetic data, it is proposed that strain $6.2 S^{\mathrm{T}}$ should be classified in the genus Sphingobacterium as representing a novel species, for which the name Sphingobacterium detergens sp. nov. is proposed.

\section{Description of Sphingobacterium detergens sp. nov.}

Sphingobacterium detergens (de.ter'gens. L. v. detergere to wipe off; L. part. adj. detergens wiping off, modern meaning surfactant, named thus for being a good surfactant producer).

Cells are Gram-negative-staining, non-motile, non-sporeforming, strictly aerobic rods, $2.5-1.8 \mu \mathrm{m}$ long and 1.0 $0.8 \mu \mathrm{m}$ wide. After $48 \mathrm{~h}$ incubation in TSA, colonies are 3$5 \mathrm{~mm}$ in diameter, beige, convex, circular and smooth with entire margins. Temperature range for growth is $15-37{ }^{\circ} \mathrm{C}$ (optimum, 30-37 ${ }^{\circ} \mathrm{C}$ ); no growth occurs at $42{ }^{\circ} \mathrm{C}$. The $\mathrm{pH}$ range for growth is 6.0-7.5 (optimum, $\mathrm{pH} 7$ ) and the $\mathrm{NaCl}$ concentration range for growth is $0-3 \%(w / v)$. Growth occurs on nutrient agar, TSA, cetrimide agar, MacConkey agar and Simmons' citrate agar. Gives a positive result for catalase, oxidase, lipase and $\beta$-galactosidase activities. Gelatin, DNA, starch, aesculin and urea are hydrolysed, but Tween 80 is not. Reduction of nitrates to nitrites gives a

Table 2. Differential characteristics between strain $6.2 S^{\top}$ and related members of the genus Sphingobacterium

Strains: $1,6.2 S^{\mathrm{T}} ; 2$, S. canadense LMG $23727^{\mathrm{T}} ; 3$, S. siyangense KCTC $22131^{\mathrm{T}}$; 4, S. multivorum DSM $11691^{\mathrm{T}}$; 5, S. thalpophilum LMG $11520^{\mathrm{T}}$. All data are from this study. All strains grow aerobically at $30{ }^{\circ} \mathrm{C}$, give a positive result in tests for catalase, oxidase and $\beta$ galactosidase activities; give a positive result for the hydrolysis of DNA, starch, aesculin and urea and for the assimilation of D-glucose, L-arabinose, melibiose, D-mannose, $\mathrm{N}$-acetylglucosamine and maltose. All strains give a positive reaction for acid production from Dglucose and sucrose. All strains give a negative result for Gram staining, sporulation, motility, indole production, Voges-Proskauer test, methyl red test, Tween 80 hydrolysis, glucose fermentation and arginine dihydrolase activity. All strains give a negative result for the assimilation of D-mannitol, L-glutamate, L-sorbitol, D-ribose, pyruvate, capric acid, adipic acid, malic acid, phenylacetic acid and for acid production from L-rhamnose, D-mannitol, sorbitol and lactose. + , Positive; -, negative. Results in parentheses indicate data from another study (Krieg et al., 2010) that differed from our results.

\begin{tabular}{|c|c|c|c|c|c|}
\hline Characteristic & 1 & 2 & 3 & 4 & 5 \\
\hline Growth at $42{ }^{\circ} \mathrm{C}$ & - & - & - & - & + \\
\hline Reduction of nitrates to nitrites & - & + & - & - & + \\
\hline \multicolumn{6}{|l|}{ Hydrolysis of: } \\
\hline Gelatin & + & + & - & - & $+(-)$ \\
\hline \multicolumn{6}{|l|}{ Assimilation of: } \\
\hline L-Rhamnose & + & $+(-)$ & + & + & $-(+)$ \\
\hline Glycerol & + & $-(+)$ & + & + & $-(+)$ \\
\hline \multicolumn{6}{|l|}{ Acid production from: } \\
\hline L-Arabinose & - & + & - & + & + \\
\hline Melibiose & - & + & - & - & - \\
\hline
\end{tabular}


Table 3. Fatty acid composition of strain $6.2 S^{\top}$ and related members of the genus Sphingobacterium

Taxa: 1 , strain $6.2 S^{\mathrm{T}} ; 2$, S. canadense LMG $23727^{\mathrm{T}}$; 3, S. siyangense KCTC $22131^{\mathrm{T}}$; 4, S. multivorum DSM $11691^{\mathrm{T}}$; 5, S. thalpophilum LMG $11520^{\mathrm{T}}$. Values are percentages of total fatty acids; components amounting to $<1.0 \%$ in all strains tested are not listed. tr, Trace $(<1.0 \%) ;-$, not detected. Values in bold type are the major fatty acids.

\begin{tabular}{|c|c|c|c|c|c|}
\hline Fatty acid & 1 & 2 & 3 & 4 & 5 \\
\hline $\mathrm{C}_{14: 0}$ & 2.23 & 1.51 & 3.36 & 3.60 & 3.07 \\
\hline $\mathrm{C}_{14: 0} 2-\mathrm{OH}$ & $\operatorname{tr}$ & $\operatorname{tr}$ & $\operatorname{tr}$ & 1.32 & - \\
\hline $\mathrm{C}_{16: 0}$ & 7.33 & 7.92 & 10.87 & 8.52 & 10.93 \\
\hline $\mathrm{C}_{16: 0} 2-\mathrm{OH}$ & $\operatorname{tr}$ & $\operatorname{tr}$ & $\operatorname{tr}$ & $\operatorname{tr}$ & 2.48 \\
\hline $\mathrm{C}_{16: 0} 3-\mathrm{OH}$ & 5.42 & 4.02 & 6.48 & 7.54 & 3.63 \\
\hline iso- $\mathrm{C}_{15: 0}$ & 20.91 & 20.48 & 16.67 & 17.56 & 20.62 \\
\hline iso- $\mathrm{C}_{15: 0} 3-\mathrm{OH}$ & 3.40 & 6.35 & 6.81 & 3.44 & 5.58 \\
\hline iso- $\mathrm{C}_{17: 0} 3-\mathrm{OH}$ & 7.40 & 8.98 & 5.37 & 5.26 & 8.67 \\
\hline Summed feature $3^{*}$ & 43.71 & 46.06 & 43.24 & 46.70 & 44.06 \\
\hline iso- $\mathrm{C}_{17: 1} \omega 9 c$ & 1.32 & $\operatorname{tr}$ & $\operatorname{tr}$ & $\operatorname{tr}$ & $\operatorname{tr}$ \\
\hline
\end{tabular}

${ }^{\star}$ Summed features represent groups of two fatty acids that cannot be separated by GLC. Summed feature 3 contains iso- $\mathrm{C}_{15: 0} 2-\mathrm{OH}$ and/or $\mathrm{C}_{16: 1} \omega 7 c$. All data are from this study.

negative result. Acid is produced from D-glucose and sucrose but not from L-rhamnose, L-arabinose, D-mannitol, melibiose, sorbitol, inositol, amygdalin or lactose. Utilizes D-glucose, L-rhamnose, L-arabinose, melibiose, glycerol, Dmannose, $\mathrm{N}$-acetylglucosamine and maltose, but not Dmannitol, L-glutamate, L-sorbitol, D-ribose, pyruvate, capric acid, adipic acid, malic acid, phenylacetic acid or gluconate. Resistant to ampicillin, aztreonam, amikacin, cephalotin, cefoxitin, colistin, chloramphenicol, erythromycin, streptomycin, fosfomycin, gentamicin, tetracycline and tobramycin. Intermediate levels of susceptibility with ciprofloxacin and ticarcillin; susceptible to amoxicillinclavulanic acid, ceftriaxone, imipenem and trimethoprimsulfamethoxazole. The predominant fatty acids are summed feature 3 (iso- $\mathrm{C}_{15: 0} \quad 2-\mathrm{OH}$ and/or $\mathrm{C}_{16: 1} \omega 7 c$ ) $(43.71 \%)$; iso- $\mathrm{C}_{15: 0}(20.91 \%)$; iso- $\mathrm{C}_{17: 0} 3-\mathrm{OH}(7.40 \%)$ and $\mathrm{C}_{16: 0}(7.33 \%)$.

The type strain $6.2 S^{\mathrm{T}}\left(=\right.$ CECT $\left.7938^{\mathrm{T}}=\mathrm{LMG} 26465^{\mathrm{T}}\right)$ was isolated in 2007 from a soil sample taken near the Lagoa de Fogo, a crater lake in the centre of the island of São Miguel in the Azores archipelago, Portugal. The $\mathrm{G}+\mathrm{C}$ content of the DNA of the type strain is $40.0 \mathrm{~mol} \%$.

\section{Acknowledgements}

We are grateful for the support of H. G. Trüper and J. P. Euzéby with the bacterial nomenclature. We thank Francesc García (Laboratori de Sanitat Vegetal, Departament d'Agricultura, Alimentació i Acció Rural, Generalitat de Catalunya, Barcelona, Spain) for assistance with the determination of the fatty acid content. The authors also thank the Ministerio de Ciencia y Tecnología (Spain) for funding this research with project CTQ2010-21183-C02/01/ppq and the Generalitat de Catalunya with project 2009SGR819.

\section{References}

Barrow, G. I. \& Feltham, R. K. A. (editors) (1993). Cowan and Steel's Manual for Identification of Medical Bacteria, 3rd edn. UK: Cambridge University Press.

Burgos-Diaz, C., Pons, R., Espuny, M. J., Aranda, F. J., Teruel, J. A., Manresa, A., Ortiz, A. \& Marqués, A. M. (2011). Isolation and partial characterization of a biosurfactant mixture produced by Sphingobacterium sp. isolated from soil. J Colloid Interface Sci 361, 195-204.

Chapin, K. C. \& Lauderdale, T. (2003). Reagents, stains and media: bacteriology. In Manual of Clinical Microbiology, 8th edn, pp. 354-383. Edited by P. R. Murray, E. J. Baron, J. H. Jorgensen, M. A. Pfaller \& R. H. Yolken. Washington, DC: American Society for Microbiology.

Duan, S., Liu, Z., Feng, X., Zheng, K. \& Cheng, L. (2009). Sphingobacterium bambusae sp. nov., isolated from soil of bamboo plantation. J Microbiol 47, 693-698.

Ezaki, T., Hashimoto, Y. \& Yabuuchi, E. (1989). Fluorometric deoxyribonucleic acid-deoxyribonucleic acid hybridization in microdilution wells as an alternative to membrane filter hybridization in which radioisotopes are used to determine genetic relatedness among bacterial strains. Int J Syst Bacteriol 39, 224-229.

Freney, J., Hansen, W., Ploton, C., Meugnier, H., Madier, S., Bornstein, N. \& Fleurette, J. (1987). Septicemia caused by Sphingobacterium multivorum. J Clin Microbiol 25, 1126-1128.

He, X., Xiao, T., Kuang, H., Lan, X., Tudahong, M., Osman, G., Fang, C. \& Rahman, E. (2010). Sphingobacterium shayense sp. nov., isolated from forest soil. Int J Syst Evol Microbiol 60, 2377-2381.

Jorgensen, J. H. \& Turnidge, J. D. (2003). Susceptibility test methods: dilution and disk diffusion methods. In Manual of Clinical Microbiology, 8th edn, pp. 1108-1127. Edited by P. R. Murray, E. J. Baron, J. H. Jorgensen, M. A. Pfaller \& R. H. Yolken. Washington, DC: American Society for Microbiology.

Kim, K. H., Ten, L. N., Liu, Q. M., Im, W. T. \& Lee, S. T. (2006). Sphingobacterium daejeonense sp. nov., isolated from a compost sample. Int J Syst Evol Microbiol 56, 2031-2036.

Kimura, M. (1980). A simple method for estimating evolutionary rates of base substitutions through comparative studies of nucleotide sequences. J Mol Evol 16, 111-120.

Krieg, N. R., Staley, J. T., Brown, D., Hedlund, B. P., Paster, B. J., Ward, N. L., Ludwig, W. \& Whitman, W. B. (2010). Genus I. Sphingobacterium Yabuuchi, Kaneko, Yano, Moss and Miyoshi 1983, 592 ${ }^{\mathrm{VP}}$. In Bergey's Manual of Systematic Bacteriology, 2nd edn, vol. 4, pp. 331-339. Edited by N. R. Krieg, J. T. Staley, D. Brown, B. P. Hedlund, B. J. Paster, N. L. Ward, W. Ludwig \& W. B. Whitman. New York: Springer-Verlag.

Larkin, M. A., Blackshields, G., Brown, N. P., Chenna, R., McGettigan, P. A., McWilliam, H., Valentin, F., Wallace, I. M., Wilm, A. \& other authors (2007). CLUSTAL W and CLUSTAL_X version 2.0. Bioinformatics 23, 2947-2948.

Liu, R., Liu, H., Zhang, C. X., Yang, S. Y., Liu, X. H., Zhang, K. Y. \& Lai, R. (2008). Sphingobacterium siyangense sp. nov., isolated from farm soil. Int J Syst Evol Microbiol 58, 1458-1462.

MacFaddin, J. F. (1980). Biochemical Test for Identification of Medical Bacteria, 2nd edn. Baltimore: Williams \& Wilkins.

Marqués, A. M., Pinazo, A., Farfán, M., Aranda, F. J., Teruel, J. A., Ortiz, A., Manresa, A. \& Espuny, M. J. (2009). The physicochemical properties and chemical composition of trehalose lipids produced by Rhodococcus erythropolis 51T7. Chem Phys Lipids 158, 110-117. 
Martínez-Murcia, A. J., Antón, A. I. \& Rodríguez-Valera, F. (1999). Patterns of sequence variation in two regions of the 16S rRNA multigene family of Escherichia coli. Int J Syst Bacteriol 49, 601-610.

Matsuyama, H., Katoh, H., Ohkushi, T., Satoh, A., Kawahara, K. \& Yumoto, I. (2008). Sphingobacterium kitahiroshimense sp. nov., isolated from soil. Int J Syst Evol Microbiol 58, 1576-1579.

Mehnaz, S., Weselowski, B. \& Lazarovits, G. (2007). Sphingobacterium canadense sp. nov., an isolate from corn roots. Syst Appl Microbiol 30, 519-524.

Mesbah, M., Premachandran, U. \& Whitman, W. B. (1989). Precise measurement of the $\mathrm{G}+\mathrm{C}$ content of deoxyribonucleic acid by high performance liquid chromatography. Int J Syst Bacteriol 39, 159-167.

Pochon, J. \& Tardieux, P. (1962). Techniques d'Analyse en Microbiologie du sol. La Tourelle, France: St. Mandé.

Rozen, S. \& Skaletsky, H. (2000). Primer 3 on the WWW for general users and for biologist programmers. In Bioinformatics Methods and Protocols: Methods in Molecular Biology, pp. 365-386. Edited by S. Krawetz \& S. Misener. Totowa, NJ: Humana Press.

Saitou, N. \& Nei, M. (1987). The neighbor-joining method: a new method for reconstructing phylogenetic trees. Mol Biol Evol 4, 406425.

Schmidt, V. S., Wenning, M. \& Scherer, S. (2012). Sphingobacterium lactis sp. nov. and Sphingobacterium alimentarium sp. nov., isolated from raw milk and a dairy environment. Int J Syst Evol Microbiol 62, 1506-1511.

Shivaji, S., Ray, M. K., Shyamala Rao, N., Saisree, L., Jagannadham, M. V., Seshu Kumar, G., Reddy, G. S. N. \& Bhargava, P. M. (1992). Sphingobacterium antarcticus sp. nov., a psychrotrophic bacterium from the soils of Schirmarcher Oasis, Antarctica. Int J Syst Bacteriol 42, 102-106.

Steyn, P. L., Segers, P., Vancanneyt, M., Sandra, P., Kersters, K. \& Joubert, J. J. (1998). Classification of heparinolytic bacteria into a new genus, Pedobacter, comprising four species: Pedobacter heparinus comb. nov., Pedobacter piscium comb. nov., Pedobacter africanus sp. nov. and Pedobacter saltans sp. nov. proposal of the family Sphingobacteriaceae fam. nov. Int J Syst Bacteriol 48, 165-177.

Takeuchi, M. \& Yokota, A. (1992). Proposals of Sphingobacterium faecium sp. nov., Sphingobacterium piscium sp. nov., Sphingobacterium heparinum comb. nov., Sphingobacterium thalpophilum comb. nov. and two genospecies of the genus Sphingobacterium, and synonymy of Flavobacterium yabuuchiae and Sphingobacterium spiritivorum. J Gen Appl Microbiol 38, 465-482.

Tamura, K., Dudley, J., Nei, M. \& Kumar, S. (2007). MEGA4: Molecular evolutionary genetics analysis (MEGA) software version 4.0. Mol Biol Evol 24, 1596-1599.

Ten, L. N., Liu, Q. M., Im, W. T., Aslam, Z. \& Lee, S. T. (2006). Sphingobacterium composti sp. nov., a novel DNase-producing bacterium isolated from compost. J Microbiol Biotechnol 16, 17281733.

Tschech, A. \& Pfennig, N. (1984). Growth yield increase linked to caffeate reduction in Acetobacterium woodii. Arch Microbiol 137, 163167.

Wayne, L. G., Brenner, D. J., Colwell, R. R., Grimont, P. A. D., Kandler, O., Krichevsky, M. I., Moore, L. H., Moore, W. E. C., Murray, R. G. E. \& other authors (1987). International Committee on Systematic Bacteriology. Report of the ad hoc committee on reconciliation of approaches to bacterial systematics. Int J Syst Bacteriol 37, 463464.

Wei, W., Zhou, Y., Wang, X., Huang, X. \& Lai, R. (2008). Sphingobacterium anhuiense sp. nov., isolated from forest soil. Int $J$ Syst Evol Microbiol 58, 2098-2101.

Wilson, K. (1987). Preparation of genomic DNA from bacteria. In Current Protocols in Molecular Biology, pp. 241-245. Edited by F. M. Ausubel, R. Brent, R. E. Kingston, D. D. Moore, J. G. Seidman, J. A. Smith \& K. Struhl. New York: Greene Publishing and WileyInterscience.

Yabuuchi, E., Kaneko, T., Yano, I., Moss, C. W. \& Miyoshi, N. (1983). Sphingobacterium gen. nov., Sphingobacterium spiritivorum comb. nov., Sphingobacterium multivorum comb. nov., Sphingobacterium mizutae sp. nov., and Flavobacterium indologenes sp. nov.: glucosenonfermenting Gram-negative rods in CDC groups IIK-2 and IIb. Int J Syst Bacteriol 33, 580-598.

Zhang, J., Zheng, J. W., Cho, B. C., Hwang, C. Y., Fang, C., He, J. \& Li, S. P. (2012). Sphingobacterium wenxiniae sp. nov., a cypermethrindegrading species from activated sludge. Int J Syst Evol Microbiol 62, 683-687. 